\title{
The offshorization of economy: the present realities
}

\author{
Olga Maslak ${ }^{1, *}$, Natalya Grishko ${ }^{1}$, Olha Hlazunova $^{1}$ and Kateryna Vorobiova ${ }^{1}$ \\ ${ }^{1}$ Kremenchuk Mykhailo Ostrohradskyi National University, Ukraine
}

\begin{abstract}
In this article the essence and main types of offshore zones have been studied. It has been analyzed the main reasons for cooperation with the tax havens, established that the main reason of the Ukrainian economy offshorization is not only the desire of economic entities to optimize taxes, but also the desire to protect their assets from the negative impact of the crisis phenomena in the national economy during 2010-2016. The foreign experience of the anti-offshore regulation has been researched. It has been defined that the general anti-offshore regulation vector should be based on the principles of financial transparency, active cooperation with the international community, an optimal combination of instruments that restrict the capital outflows and the effective instruments that stimulate the business development in the country. It has been also established that the mechanism of deoffshorization should be aimed not only at elimination of the territories with the preferential taxation, but also at receiving benefits from their use on the basis of the existing financial infrastructure of the leading world offshore centers. The experience of China in attracting additional foreign investments, gaining wider access to financial resources through the cooperation with an offshore financial centre has been researched.
\end{abstract}

Key words: offshore, economy, taxes, regulation

\section{Introduction}

Today the most important problem of the sustainable economic development in many countries is the high level of their offshorization, the withdrawal of capital outside the state in order to optimize taxation, the "super profits" obtaining and the maintaining the incognito status at the same time.

Offshores are traditionally considered as the countries as well as the individual districts in some countries which have the preferential tax regime or no taxes in certain cases. Some tax havens represent the regime of the full or partial confidentiality of information concerning business transactions, cash flows, and foreign companies' property. Sometimes tax havens even ensure the anonymity of the company owners [1].

\footnotetext{
* Corresponding author: oimaslak2017@gmail.com
} 


\section{Data and Methods}

In the article it has been used such scientific methods as the method of analysis and synthesis, generalizations, comparison, induction and deduction, graphical methods.

Research and analytical materials, data provided by the famous information portals and agencies, articles of the scientists-economists devoted to the chosen problems were used for the determination of the offshores' essence, the modern tax havens types, and the analysis of the world practice of their use. In order to identify the main motives of Ukrainian residents for the capital withdrawal from the domestic jurisdiction, relevant statistical information concerning the socio-economic situation in the country was used. For this purpose the official figures provided by the State Statistics Service of Ukraine and the National Bank of Ukraine were used.

\section{Results}

Global Financial Integrity published the data concerning the capital's illegal outflow from the developing countries. Herewith, China was the leader of the capital outflow. It should be noted that annually near 139 billion dollars are illegally withdrawn from this country. In the second place was Russia (\$ 104,977 billion annually) [2;3]. Ukraine was in the 14th place in the ranking with about $\$ 11,7$ billion of the annual amount of illegal capital outflow.

There is no single list of the offshore zones. The International Monetary Fund (IMF) and the central banks of different countries perform the control of them [4]. Due to those opportunities which a country has in the sphere of the tax optimization, we can group them as follows (Table 1).

Table 1. The offshore zones grouping based on taxation (based on $[5 ; 6]$ )

\begin{tabular}{|c|c|}
\hline Group of countries & Features of taxation \\
\hline $\begin{array}{l}\text { United Arab Emirates, Belize, British } \\
\text { Virgin Islands, Seychelles, Cayman } \\
\text { Islands, Cook Islands, Dominica, } \\
\text { Panama, Anguilla, St. Kitts and } \\
\text { Nevis, Commonwealth of the } \\
\text { Bahamas, Turks and Caicos, Saint } \\
\text { Vincent }\end{array}$ & $\begin{array}{l}\text { The offshore zones with zero taxation. Companies registered } \\
\text { in these offshore zones have the right to conduct business all } \\
\text { over the world, with the exception of the country of } \\
\text { registration; they are completely exempted from taxation and } \\
\text { information reporting. The simplified company registration } \\
\text { process, confidentiality, flexible and understandable } \\
\text { legislation }\end{array}$ \\
\hline $\begin{array}{l}\text { Hong Kong, Singapore, Gibraltar, } \\
\text { Isle of Man }\end{array}$ & $\begin{array}{l}\text { Companies registered in these offshore zones have the right } \\
\text { to conduct business all over the world, with the exception of } \\
\text { the country of registration. The largest financial centers, } \\
\text { companies registered under their jurisdiction, are exempt } \\
\text { from taxes, but in any case the information reporting is } \\
\text { obligatory. If the company operates in Singapore or opens } \\
\text { accounts in Singapore banks, the tax will be } 17 \%\end{array}$ \\
\hline $\begin{array}{l}\text { Cyprus (tax is up to } 10 \%) \text {, Great } \\
\text { Britain }(20-26 \%) \text {, Malta }(5-35 \%)\end{array}$ & $\begin{array}{l}\text { Low tax companies in the non-offshore jurisdictions. } \\
\text { Companies registered in these jurisdictions have the right to } \\
\text { conduct business all over the world, including the country of } \\
\text { registration. These jurisdictions are not "offshore" and are } \\
\text { not subject to possible restrictions on the movement of } \\
\text { financial flows }\end{array}$ \\
\hline
\end{tabular}

Cyprus is the leader in the number of offshore companies with the Ukrainian owners. There are 136 enterprises on this island which theoretically could pay taxes to the budget of 
Ukraine. The British Virgin Islands and the Seychelles are in the 2nd and 3rd place with 50 and 20 Ukrainian companies accordingly. The next offshores have the smaller number of Ukrainian companies. For example, Luxembourg - 5, Switzerland - 4, Jersey - 3, Malta -3 , the Federation of Saint Kitts and Nevis - 3, Hong Kong - 2, the Cayman Islands - 2, the Republic of Singapore - 2, The United States Virgin Islands - 1, the Bermuda Islands 1, Bulgaria - 1, Gibraltar - 1, the Marshall Islands - 1, the United Arab Emirates - 1, the Isle of Man - 1. And there are also 28 companies, which are listed in declarations as registered in Russia [7].

Accordingly, the volumes of funds invested from the territory of Ukraine abroad are distributed. The prevailing part of the Ukrainian direct investment goes to Cyprus: 5925, 1 million USD in 2014, 5926, 1 million USD in 2015 and 5923, 7 million USD in 2016. These sums represent $88,4 \%, 91,9 \%$ and $93,8 \%$ respectively of the total amount of the invested domestic capital (Table 2).

Some funds, which have been withdrawn from the national economy in this way, are returned in the form of the direct investments through the affiliated companies of domestic entrepreneurs in the offshore areas. In the structure of the foreign direct investment directed to Ukraine Cyprus has a significant share. It was 33\% in 2014, 3,4\% in 2015 and $28,3 \%$ in 2016 (Table 3). In 2016, Ukraine received 6184,7 million USD from the Netherlands, which represented $17,1 \%$ of the total volume of foreign investments.

The main reason for the national economy offshorization is the economic entities' desire to optimize taxes and to obtain additional profit from this. According to the World Bank, the tax system of Ukraine is partly burdensome. This applies not only to the tax rates, but also to the processing and filing tax information. It takes 356 hours to fill all necessary documents and pay taxes in Ukraine. At the same time, these procedures take much less time in most European countries, for example, in Poland - 271, in the Czech Republic 234, in Germany - 218, in Sweden - 122 hours [8].

Tab. 2. Direct investments from Ukraine to the economies of the world $[9 ; 10]$

\begin{tabular}{|c|c|c|c|c|c|c|c|}
\hline Partner country & 2010 & 2011 & 2012 & 2013 & 2014 & 2015 & 2016 \\
\hline \multicolumn{8}{|c|}{ million USD } \\
\hline Total & 5760,5 & 6402,8 & 6435,4 & 6568,1 & 6702,9 & 6456,2 & 6315,2 \\
\hline Netherlands & - & - & 0,1 & 13,5 & 14,2 & 12,5 & 11,2 \\
\hline Russian Federation & 166,1 & 190,3 & 236,6 & 292,6 & 377,9 & 196,4 & 122,8 \\
\hline Cyprus & 5336,1 & 5900,1 & 5899,7 & 5917,6 & 5925,1 & 5926,1 & 5923,7 \\
\hline British Virgin Islands & 20,8 & 25,8 & 25,8 & 25,8 & 25,8 & 25,8 & 51,3 \\
\hline China & 0,7 & 0,7 & 0,9 & 0,9 & 1,3 & 1,4 & 1,3 \\
\hline \multicolumn{8}{|c|}{ in $\%$ to the total volume } \\
\hline Netherlands & - & - & 0,00 & 0,21 & 0,21 & 0,19 & 0,18 \\
\hline Russian Federation & 2,88 & 2,97 & 3,68 & 4,45 & 5,64 & 3,04 & 1,94 \\
\hline Cyprus & 92,63 & 92,15 & 91,68 & 90,10 & 88,40 & 91,79 & 93,80 \\
\hline British Virgin Islands & 0,36 & 0,40 & 0,40 & 0,39 & 0,38 & 0,40 & 0,81 \\
\hline China & 0,012 & 0,011 & 0,014 & 0,014 & 0,019 & 0,022 & 0,021 \\
\hline
\end{tabular}


Tab. 3. Direct investments from the economies of the world to Ukraine, at the beginning of year $[9 ; 10]$

\begin{tabular}{|c|c|c|c|c|c|c|c|}
\hline Partner countries & 2010 & 2011 & 2012 & 2013 & 2014 & 2015 & 2016 \\
\hline 1 & 2 & 3 & 4 & 5 & 6 & 7 & 8 \\
\hline \multicolumn{8}{|c|}{ million USD } \\
\hline Total & 38992,90 & 45370,00 & 48197,60 & 51705,30 & $\mathbf{5 3 7 0 4 , 0 0}$ & 40725,40 & 36154,50 \\
\hline Austria & 1674,7 & 1798,9 & 2317,5 & 2476,9 & 2314,0 & 1648,7 & 1559,8 \\
\hline United Kingdom & 2234,1 & 2229,9 & 2536,4 & 2496,9 & 2768,2 & 2153,4 & 1790,3 \\
\hline Netherlands & 7461,3 & 11389,8 & 9323,8 & 8727,6 & 9007,5 & 6986,7 & 6184,7 \\
\hline Germany & 6009,6 & 5001,2 & 5329,8 & 4496,3 & 2908,4 & 2105,2 & 1598,2 \\
\hline Russian Federation & 1900,2 & 2692,7 & 2876,1 & 3040,5 & 3525,9 & 2338,9 & 3036,9 \\
\hline France & 1381,1 & 2105,4 & 1993,1 & 1510,3 & 1520,5 & 1394,6 & 1305,4 \\
\hline Switzerland & 785,7 & 852,7 & 939,3 & 1097,6 & 1351,0 & 1391,5 & 1390,8 \\
\hline Sweden & 674,2 & 1108,9 & 1141,9 & 1084,4 & 439,3 & 360,2 & 328,9 \\
\hline Cyprus & 8603,1 & 9620,5 & 12700,8 & 15907,7 & 17725,6 & 12769,4 & 10239,5 \\
\hline British Virgin Islands & 1283,6 & 1384,9 & 1580,2 & 1888,2 & 2275,9 & 1988,3 & 1715,0 \\
\hline USA & 1260,0 & 1107,6 & 966,6 & 976,5 & 934,7 & 701,6 & 634,1 \\
\hline Hong Kong & 4,6 & 13,0 & 14,4 & 23,0 & 20,6 & 12,4 & 9,3 \\
\hline China & 11,8 & 12,7 & 14,8 & 18,2 & 25,5 & 21,0 & 18,6 \\
\hline \multicolumn{8}{|c|}{ in $\%$ to the total volume } \\
\hline Austria & 4,29 & 3,96 & 4,81 & 4,79 & 4,31 & 4,05 & 4,31 \\
\hline United Kingdom & 5,73 & 4,91 & 5,26 & 4,83 & 5,15 & 5,29 & 4,95 \\
\hline Netherlands & 19,14 & 25,10 & 19,34 & 16,88 & 16,77 & 17,16 & 17,11 \\
\hline Germany & 15,41 & 11,02 & 11,06 & 8,70 & 5,42 & 5,17 & 4,42 \\
\hline Russian Federation & 4,87 & 5,93 & 5,97 & 5,88 & 6,57 & 5,74 & 8,40 \\
\hline France & 3,54 & 4,64 & 4,14 & 2,92 & 2,83 & 3,42 & 3,61 \\
\hline Switzerland & 2,01 & 1,88 & 1,95 & 2,12 & 2,52 & 3,42 & 3,85 \\
\hline Sweden & 1,73 & 2,44 & 2,37 & 2,10 & 0,82 & 0,88 & 0,91 \\
\hline Cyprus & 22,1 & 21,2 & 26,4 & 30,8 & 33,0 & 31,4 & 28,3 \\
\hline British Virgin Islands & 3,29 & 3,05 & 3,28 & 3,65 & 4,24 & 4,88 & 4,74 \\
\hline USA & 3,23 & 2,44 & 2,01 & 1,89 & 1,74 & 1,72 & 1,75 \\
\hline Hong Kong & 0,012 & 0,029 & 0,030 & 0,044 & 0,038 & 0,030 & 0,026 \\
\hline China & 0,030 & 0,028 & 0,031 & 0,035 & 0,047 & 0,052 & 0,051 \\
\hline
\end{tabular}

In 2016 due to the criterion of the tax payments convenience Ukraine ranked 84th. The general tax rate, including all types of fiscal payments, is $51.9 \%$. Although there is a world tendency to reduce the tax burden on business. So that the general tax rate of the rating leaders does not exceed 20\%: for example, in the United Arab Emirates it is 11,3\%, in Qatar - 15,9\% [11].

Nevertheless, in the modern economic conditions the desire to protect the assets from the influence of internal and external risks and from the threats to the effective entrepreneurial activity become the more important determinant of capital withdrawal abroad by residents of Ukraine. The increasing of these factors' importance is caused by the destabilization of the socio-economic situation, the reduction of the Ukrainian economy investment attractiveness and the increasing of political and legal risks impact. Thus, in recent years there has been a significant decrease in the physical volume of the gross domestic product of Ukraine: in 2014 - by 6, 6\%, in 2015 - by 9,9\% (Fig. 1). 


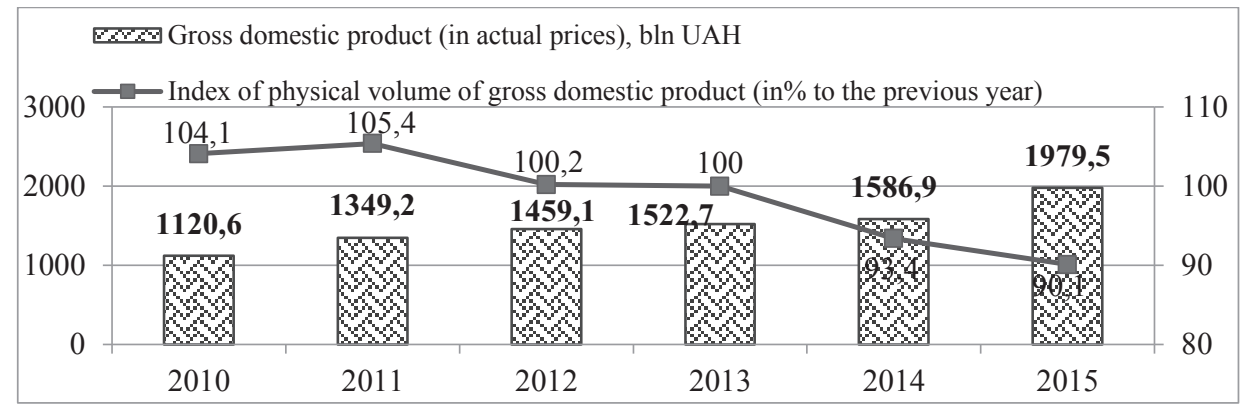

Fig. 1. The Ukrainian GDP dynamics in actual prices and prices of the previous year ( $\%$ to the previous year) [9]

At the same time, the nominal GDP was characterized by the positive dynamics. Such a "fictitious" increase of the gross value added amount created on the Ukrainian territory in 2014-2015 was due to, first of all, the significant inflation increase (Fig. 2).

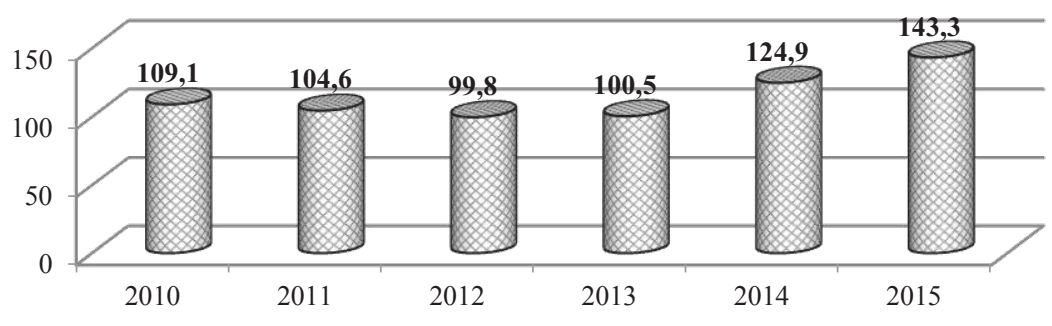

Fig. 2. The Ukrainian consumer price index dynamics during 2010-2015, \% [11]

In Ukraine the consumer price index was $124,9 \%$ in 2014 and $143,3 \%$ in 2015 . The depreciation of the national currency is an indicator of a significant weakening of the national economy and a threat of the further regression of the domestic business entities development.

In the period from 2013 to 2014 , the gross external debt of Ukraine increased: by 6 , $65 \%$ in 2013 and by 5,54\% in 2014 (Fig. 3). At the same time, in 2014 the amount of the external debt exceeded the gross domestic product of the same period by $7,79 \%$. The attention should be paid to the fact that in 2015 and 2016 the amount of the state debt of Ukraine decreased by $11,1 \%$ in 2015 and by $6 \%$ in 2016 . However, in 2015 the external debt amounted to $139,39 \%$ in relation to the GDP. It was a historic record and it was the result of a decrease in the amount of the value added created in Ukraine and further devaluation of hryvnia. At the same time, the results of domestic and foreign researches indicated that the amount of the public debt of Ukraine could be economically safe at the level of $35 \%$ of GDP [12]. 


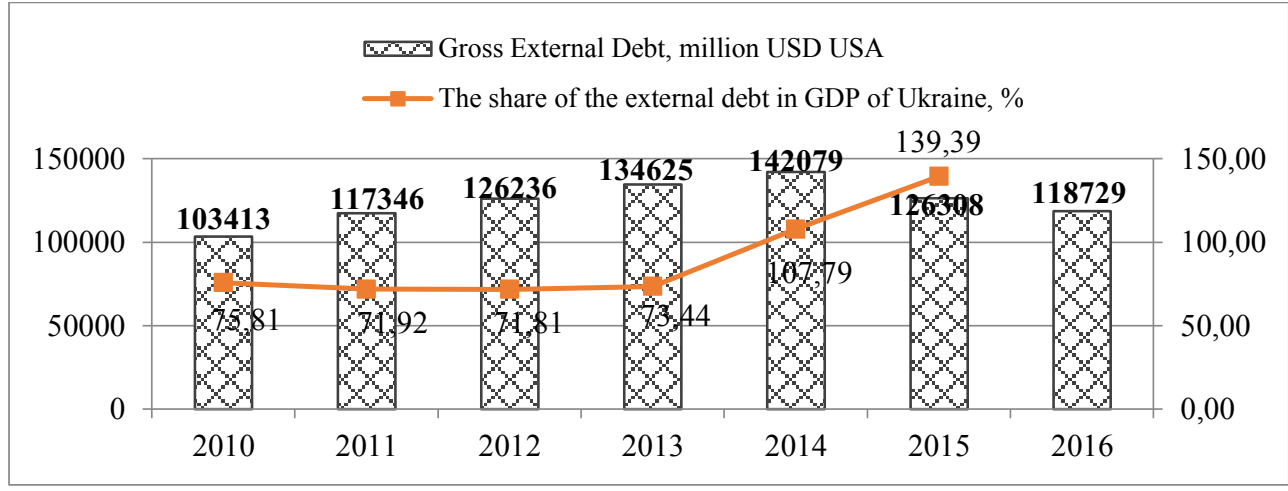

Fig. 3. The Ukrainian gross external debt dynamics during 2010-2016 [10]

The growth of capital outflows has a significant negative impact on the national currency stability, financial security level and general economic stability of the state.

That is why today the deoffshorization process is gaining momentum both at the national and international levels. The latest trend in the EU is the implementation of the European Parliament directive aimed at combating the money laundering and tax evasion, in particular through the use of the offshore schemes. New requirements for law firms, banks and other financial institutions concerning the conduction of the register of clients' final beneficiaries and providing this information to the financial monitoring services are introduced. The first financial information disclosure is announced in 2017 by such countries as the British Virgin Islands, Cyprus, Lithuania, Latvia, Luxembourg, the Netherlands and Seychelles. In 2018 Austria, Hong Kong, Monaco, Russia, Singapore, Switzerland and others countries will exchange the information for the first time. But Panama and Ukraine are not represented in this list [13].

The work of the international organizations in the sphere of the offshore business regulation is aimed, first of all, at the development of legislative regulations and rules intended to limit and regulate the offshore business, as well as to monitore their implementation completeness.

A variety of tools are used to ensure the high level of financial transparency and to prevent capital outflows through the tax havens at the national level. In this case, both loyal preventive measures and rigid (aggressive) methods, which include penal sanctions and other types of legal proceedings, are implemented (Table 4 in Discussion).

Thus the deoffshorization's tools can be nominally divided into three big groups: tools with the restrictive nature, tools that stimulate respondents to conduct business under the domestic jurisdiction and tools that help to benefit from the use of the offshore schemes.

The tools with the restrictive nature include the ensuring of exchange the information concerning the domestic taxpayers' accounts in foreign jurisdictions with the international financial organizations, the conclusion of the double taxation avoidance contracts, currency restrictions, etc. There are the following stimulating tools: the national tax regime optimization, the increase of the favorable investment climate in the state. The tools that enable to get the benefits include the creation of its own offshore zones, the use of offshores for the purpose of foreign economic expansion.

Especially interesting is the experience of China. This country uses offshore zones to attract the additional foreign investment and to gain wider access to financial resources.

Herewith, the use of the offshore zones is carried out within the framework of state programs, but the monetary control of the capital movement is also maintained. China has concluded more than 120 tax information exchange agreements, including the major offshore jurisdictions. This situation allows us to detect schemes for the tax evasion. Most 
of foreign investment goes to China through Hong Kong. The Hong Kong Special Administrative Region serves as an example of a "traditional" international financial center, which represents some signs of the offshore at the same time.

Hong Kong is the leader of economic freedom ranking which is published by The Heritage Foundation. In addition, Hong Kong has a high level of legal culture that attracts investors and entrepreneurs from around the world. Hong Kong refers to the countries with the preferential taxation, aimed mainly at stimulating the inflow of foreign investors in certain sectors of the economy, including the securities market. In Hong Kong the income tax is $17,5 \%$, while dividends, interest and capital gains are not taxed. The transparency of Hong Kong's economy as a whole and the financial system in particular is so high and the taxes are so low, that this fact allows the Bank for International Settlements to classify Hong Kong as the offshore center.

In the mid-2000s, the Chinese government took a number of steps to intensify the use of foreign markets, first of all, the market of Hong Kong, to attract capital to Chinese enterprises and banks. As a result, Hong Kong financial market became a significant source of capital not only for local companies, but also for companies registered in China. This caused a very serious interest in this market from foreign investors.

\section{Discussion}

Tab. 4. Foreign experience in the sphere of the economy deoffshorization $[14 ; 15 ; 16 ; 17]$

\begin{tabular}{|c|c|}
\hline Country & The main tools and methods of the economy deoffshorization \\
\hline 1 & 2 \\
\hline Poland & $\begin{array}{l}\text { The government of the country set the course towards the creation of favorable conditions } \\
\text { which could contribute to the flow of capital into the country. Cooperation with the } \\
\text { offshore zones is quite legitimate in Poland; there are no obstacles for this process at the } \\
\text { institutional level. The state has its own list of the countries with the "harmful tax } \\
\text { competition". There are certain rules which are applied in relations with the countries from } \\
\text { this list: } \\
\text { - income tax on transactions, royalties, interest and certain types of intangible services is } \\
20 \% \text {; } \\
\text { - the Polish tax authorities can decide on the determination of the income amount from } \\
\text { transactions with a company registered in an offshore area. Such an operation may be } \\
\text { subject to an additional } 50 \% \text { tax on the difference between the income declared by the } \\
\text { taxpayer and calculated by the tax authorities; } \\
\text { - reimbursement of VAT on the received or rendered services in or from an offshore zone } \\
\text { is prohibited; } \\
\text { - it is important to conduct a more detailed review of the transfer pricing, which means the } \\
\text { need to provide tax and customs authorities with more detailed documentation on } \\
\text { transactions with companies that are registered in the countries with so-called harmful tax } \\
\text { competition }\end{array}$ \\
\hline Estonia & $\begin{array}{l}\text { Revenues, received by enterprises, which are immediately redistributed, are not taxable. } \\
\text { Export and transit transactions are not subject to VAT. In this regard, Estonia is } \\
\text { considered as an offshore zone in the jurisdictions of many countries, although this is not } \\
\text { quite the case. In the absence of the income tax Estonian companies maintain accounting } \\
\text { records. They report twice a month to the tax authorities and every "unauthorized" use of } \\
\text { funds leads to the additional tax payment in the amount of } 79,9 \% \text { of the withdrawn sum. } \\
\text { There are no restrictions in Estonia on cooperation with the offshore zones. However, the } \\
\text { website of the tax department presents an informal "black list". Payments to the states } \\
\text { from this list are the subject to the } 21 \% \text { profit tax. }\end{array}$ \\
\hline
\end{tabular}


USA $\quad$ In 2008 the Stop Tax Haven Abuse Act was passed in the USA. According to this Act the fiscal and controlling authorities obtained the widest powers towards the taxpayers who resorted to offshore schemes. The amount of the fine could reach $150 \%$ of the gained profit.

The adoption of the Foreign Account Tax Compliance Act in 2010 became one of the key events in the development of the anti-offshore legislation in the United States. The law obliged citizens to declare all their incomes, regardless of the country of their origin. The use of offshores is allowed only for the business development. In all other cases, the presumption of the enterprise guilt is established, it has to refute the presence of the hidden revenues in the tax havens.

After the adoption of FATCA (Foreign Account Tax Compliance Act) the US Department of the Interior got the right to receive any information about the accounts and assets of its citizens abroad. Banks, that refused to comply with such requirements, were required to pay $30 \%$ of any transactions passing through the US, otherwise their accounts in financial institutions of the United States might be closed.

A new Tax Reform project for the commercial sector, which was presented to the public in 2012, stipulated the obligatory payment of the tax on income received in the territory of other countries. The same document lifted a deferral from the payment of such tax on income until the moment of its repatriation (return under the domestic jurisdiction)

\begin{tabular}{|c|c|}
\hline & Continuation of Table 4 \\
\hline 1 & 2 \\
\hline $\mathbf{U K}$ & $\begin{array}{l}\text { First of all, the government of this country seeks to optimize the state tax system. For this } \\
\text { purpose in } 2011 \text { the corporate tax rate was reduced from } 28 \% \text { to } 26 \% \text {, while the rates for } \\
\text { small businesses decreased to } 20 \% \text {. } \\
\text { There are the following main legislative acts regulating the residents' offshore activities: } \\
\text { 1. The Offshore Funds (Tax) Regulations, } 2009 \text {; } \\
\text { 2. Taxation (International and Other Provisions) Act, } 2010 \text {; } \\
\text { 3. Companies Act, } 2006 \text {. } \\
\text { These legislative acts define the types of legal entities that can register non-residents on } \\
\text { the territory of the country and regulate their taxation. In } 2011 \text { new fines for taxpayers } \\
\text { were introduced in the UK. They are used by affiliated companies registered in the } \\
\text { offshore jurisdictions to avoid full compliance with tax obligations }\end{array}$ \\
\hline France & $\begin{array}{l}\text { The use of the anti-offshore regulation's "preventive" measures is typical for France. } \\
\text { There is no special legislation in the sphere of banking secrecy in the country. At least } \\
\text { once a month banking institutions provide information regarding the facts of opening and } \\
\text { closing accounts, the size of the interest or income from the capital received by customers. } \\
\text { In turn, the tax service directs and makes the appropriate changes to resident bank } \\
\text { accounts' centralized unified database. } \\
\text { France belongs to the countries with an active position in the fight against the } \\
\text { offshorization. The banks of this country took a decision to discontinue operations on the } \\
\text { territory of the countries which were in the "gray list" of the OECD. All the financial } \\
\text { institutions should report on transactions with jurisdictions that have not signed the tax } \\
\text { information exchange agreement }\end{array}$ \\
\hline China & $\begin{array}{l}\text { The offshorization is considered as the inevitable result of the world economy's } \\
\text { functioning mechanism transformation. China wants to benefit for the national economy } \\
\text { from the use of the offshore jurisdictions. It uses the offshore zones as the mean to } \\
\text { increase the industrial exports competitiveness, to get wider access to the financial } \\
\text { resources, to increase the volumes of foreign investments into the raw material extraction } \\
\text { and infrastructure development. The goal is also to provide access to Hong Kong's } \\
\text { financial resources, including the direct lending, issue of yuan bonds at the Hong Kong } \\
\text { Stock Exchanges, attraction of funds, listing on foreign exchanges of Chinese companies } \\
\text { operating in industries closed to foreign companies. }\end{array}$ \\
\hline
\end{tabular}




\section{Conclusion}

Thus, the problem of the national economy offshorization is particularly acute for Ukraine in terms of financial, economic, political and legal instabilities; therefore, the development of the effective instruments for regulating the relations of residents with "tax havens" needs to be given increased attention. In the general sense, the mechanism of the national economy deoffshorization is a set of interacting tools and subsystems that ensure of the state tax system optimization and return to domestic capital jurisdiction through the establishment of the effective communication between economic entities, national and international institutional bodies, fiscal services and the financially-credit system of the country.

\section{References}

1. O. Volotovskaya, M., V. Zakharova. Offshore schemes as a threat to the economic security of the Russian Federation (2014)

2. D. Sushkevych, The capital outflow from developing countries: causes and consequences. Case study of the republic of Belarus (2016)

3. Global Financial Integrity [online], Available at: http://www.gfintegrity.org/ (2017)

4. Offshore zones: classification, location, methods. Reference [online], Available at: https://ria.ru/economy/20090403/166953816.html (2009)

5. Offshore zones - the list and comparison of offshore zones of the world [online], Available at: http://www.bcs-offshore.com/rating.html (2017)

6. L. Opekarová, V. Mulačová, H. Ezrová, R. Píchová, Tax harmonisation in free trade EU - reflection on the possibilities of tax evasion - part 1, Littera Scripta, 4(1), 61-77 (2011)

7. Top 5 of the offshore owners: Liovochkin's sister headed the list - infographics [online], Available at: http://zik.ua/news/2016/11/27/top5 vlasnykiv ofshoriv spysok ocholyla sestra lovochkina infografika 998527 (2017)

8. Y. Gryhoreva, Theoretical and methodological approaches to assessing the consequences of offshore business for the development of modern international capital flows. Economy and society, 6(25) (2016)

9. State Statistics Service of Ukraine [online], Available at: http://www.ukrstat.gov.ua/ (2017)

10. National bank of Ukraine [online], Available at: https://www.bank.gov.ua/control/ uk/index (2017)

11. O. Liakhovets, Entrepreneurship as a component of modernization institutional environment. Scientific Journal of International Humanitarian University (2016)

12. M. Ivanchenko, K. Dobrolezha, A. Chubak, The analysis of Ukraine debt at the present conditions. Global and National Problems of Economy, 10, $792-797$ (2016)

13. Global deoffshorization: its consequences for Ukraine [online], Available at: http://forbes.net.ua/ ua/opinions/1414948-globalna-deofshorizaciya-yaki-yiyi-naslidkidlya-ukrayini (2017)

14. Ukraine and the United States signed an agreement within the FATCA law on the fulfillment of requirements to the foreign accounts [online], Available at: https://economics.unian.net/finance/1764856-ukraina-i-ssha-podpisali-soglashenie-vramkah-zakona-fatca-o-vyipolnenii-trebovaniy-k-inostrannyim-schetam.html (2017)

15. A. Faruki, A. Tsaruev, EC Policy Towards Offshores. Scientific student's conference, Offshores in international business practice, 4(23) (2012) 
16. N. Yurchenkova, The deofshorization is gaining momentum: the first results of the reform. Corporate lawyer, 6, 10-14 (2016)

17. Y. Danilov, The experience of financial markets reforms in the countries - competitors of Russia in the global capital market. Research Paper Series, 2016(171), 156 (2016) 